\title{
МІНІМАЛЬНА СЕМАНТИКО-СИНТАКСИЧНА ОДИНИЦЯ У ФУНКЦІї АДРЕСАТА
}

Межов О. Г. Мінімальна семантико-синтаксична одиниця у функції адресата.

У статті проведено системне дослідження адресатних синтаксем сучасної української літературної мови на матеріалі різностильових текстів у зв'язку з семантичними і валентними типами предикатів. Описано семантичні та морфологічні варіанти категорії адресатності в елементарних та неелементарних простих реченнях, її лексичне наповнення. Визначено способи ускладнення адресатної семантики іншими значеннями.

Ключові слова: мінімальна семантико-синтаксична одиниця, синтаксема, адресатна синтаксема, предикат, давальний відмінок.

Межов А. Г. Минимальная семантико-синтаксическая единица в функции адресата.

В статье проведено системное исследование адресатных синтаксем современного украинского литературного языка на материале разностилевых текстов в связи с семантическими и валентными типами предикатов. Описаны семантические и морфологические варианты категории адресата в элементарных и неэлементарных простых предложениях, ее лексическое наполнение. Определены способы осложнения адресатной семантики другими значениями.

Ключевые слова: минимальная семантико-синтаксическая единица, синтаксема, адресатная синтаксема, предикат, дательный падеж.

Mezhov A. G. Minimal semantic-syntactical unit in the function of addressee.

In the article system research of addressee sintaxem modern literary Ukrainian is conducted on material of texts of different styles in connection with the semantic and valency types of predicates. The semantic variants of category of addressee are described in the elementary and unelementary simple sentences, its lexical filling. The methods of complication of addressee semantics are definited by other values.

Key words: minimal semantic-syntactical unit, sintaxema, addressee, predicate, dativ.

У сучасному українському мовознавстві набуває поширення вчення про три синтаксичні одиниці: речення, словосполучення й мінімальну синтаксичну одиницю. Речення i словосполучення $є$ синтаксичними одиницями-конструкціями, а мінімальна синтаксична одиниця функціонує як їхній компонент. Функціональний багатоаспектний аналіз мінімальних 
синтаксичних одиниць є одним 3 актуальних завдань сучасної граматики. У цьому плані потребує грунтовного вивчення сукупність адресатних синтаксем як визначального різновиду субстанціальних компонентів речення. Мінімальна семантико-синтаксична одиниця у функції адресата $\epsilon$ важливим компонентом семантико-синтаксичної структури простого речення слов'янських мов. Вона разом із суб'єктом, предикатом та іншими синтаксемами формує семантично елементарні конструкції мовної системи, тому без усебічного дослідження цієї мінімальної одиниці не можна глибоко пізнати природу речення як основної синтаксичної одиниці, а без цього неможлива побудова викінченої синтаксичної теорії.

Проблеми семантичної категорії адресатності (адресатної синтаксеми) досліджували Є. К. Тимченко, I. Р. Вихованець, К. Г. Городенська, Й. Ф. Андерш, А. П. Загнітко, М. Я. Плющ, М. В. Мірченко, Т. Є. Масицька та ін., однак спеціальної праці, присвяченої комплексному аналізу адресатної синтаксеми, немає. Метою пропонованої статті є детальний опис семантичних варіантів адресатної мінімальної семантикосинтаксичної одиниці в елементарних та ускладнених простих реченнях сучасної української літературної мови; з'ясування впливу семантичних i валентних типів предикатів на семантичне варіювання категорії адресатності та іiі лексичне наповнення; вивчення механізму ускладнення адресатної семантики іншими значеннями; аналіз відмінкових i прийменниково-відмінкових форм як морфологічних варіантів адресата. Дослідження побудовано на реченнєвих конструкціях, дібраних 3 різностильових текстів сучасної української літературної мови.

У сукупності іменникових синтаксем адресатна мінімальна семантико-синтаксична одиниця посідає периферійне місце і в типовому вияві характеризується рядом диференційних семантико-синтаксичних ознак, серед яких варто виділити субстанціальність, валентну пов'язаність iз предикатом дії, пасивність. Адресатний компонент може мати як облігаторний, так і факультативний вияв, оскільки наявність чи відсутність його в реченні зумовлюється особливостями відбиття позамовної дійсності в різноманітних проявах та специфікою комунікації. Він найчастіше представлений в українській, як і багатьох інших слов'янських мовах, давальним відмінком.

Адресатне значенння давального відмінка в слов'янських та інших мовах індоєвропейської сім’ї, як слушно зауважує М. Я. Плющ, $є$ наслідком граматикалізації цього відмінка i перетворення його 3 семантичного на синтаксичній. Однак на відміну від багатьох мов, які характеризуються дво-, три- або чотиривідмінковою системою парадигм іменників, що склалася внаслідок завершення або майже повного завершення нейтралізації опозиції «датив / акузатив», у слов’янських мовах, зокрема i в українській, давальний у своїх основних значеннях функціонує як конкретний, семантичний, слабкокерований відмінок, 
здатний самостійно поширювати предикат чи предикативну основу речення [6, с. 45]. Покликаючись на Є. Куриловича у визначенні первинної функції давального відмінка в німецькій мові, Й. Ф. Андерш підкреслює, що його позиція в слов'янських мовах більш вільна, конкретне значення відображає зв'язки предметів в об’єктивній дійсності, в той час як власне об'єктне значення зумовлюється граматичними факторами, передусім сильним керуванням [1, с.16-17]. Адресатна синтаксема належить до правобічних субстанціальних компонентів семантично елементарного простого речення, що вказує на особу або іншу істоту, на користь або на шкоду якої відбувається дія [3, с. 125; 4, с. 73]. Порівняно з іншими іменниковими синтаксемами адресатній властива найменша семантична розгалуженість. Вона здатна валентно сполучатися лише 3 деякими дієслівними предикатами, похідними від них віддієслівними іменниками та окремими прикметниковими предикатами. Серед дієслівних предикатів, які беруть участь у вираженні категорії адресатності, є тільки предикати дії, для яких характерна семантика: 1) «давання»; 2) «писання»; 3) «перенесення»; 4) «перевезення». Детально проаналізуємо дієслова кожної з цих лексикосемантичних груп. Найбільш спеціалізовані на вираженні спрямованості дії на адресат тривалентні дієслова із семантикою «давання», які вказують на передавання об'єкта певному адресату: адресувати, давати, видавати, віддавати, надавати, передавати, подавати, роздавати, вручати, доручати, дарувати, присвячувати, пропонувати, платити, позичати, продавати, придбати, купувати, залишати, слати, надсилати, пересилати і под. Відповідно адресатну синтаксему обов'язково має супроводжувати об'єкт дії. Напр.: Воєвода Мостовик свого часу віддав значну прислугу великому князеві (П. Загребельний); Влада сама мені видала документ на право продавати бульбашки (В. Лис); - Я передам вашому дільничному лікареві, щьоб він до вас зайшов (А. Дімаров); Він дарував розкішні букети нареченим (В. Симоненко); Мудрий Пірі Мехмед прислав шовковий згорток Сулейманові (П. Загребельний); Вона могла б купити Івану спокій за свою ласку (І. Кочерга); - У нас теж дещзо приховано. Можем і позичити тобі за тяжкий труд, як хочеш (Григорій Тютюнник); Ти чесна жінка, ти не продаєш своєї вроди й пестощзів йому за гроші (Леся Українка).

Передачу об'єкта адресату можуть виражати чотиривалентні дієслова iз семантикою «писання» на зразок писати, виписувати, відписувати, вписувати, дописувати, надписувати, переписувати, підписувати, повідписувати, попереписувати, попідписувати, розписувати $і$ m. ін., які свою правобічну валентність реалізують за допомогою адресатної, об’єктної та інструментальної синтаксем (остання здебільшого не має імпліцитного вираження), напр.: Як завжди, Тимофій відписував сестрі синьою ручкою (О.Де); Світлий радісний бог Аполлон написав вогняними стрілами прекрасній Дафні про силу свого безмежного кохання (М. Кун); Написать Тарасові правду - все одно щзо пхнути його ножем у саме серизе! ... (I. Драч); 


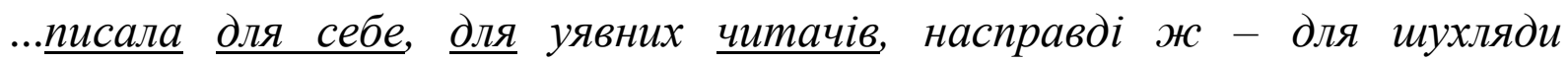
(«Літературна Україна»); Протягом 1926 р. Плужник писав для читачів свою периу книгу віриів «Дні» («Історія української літератури ХХ ст.»);

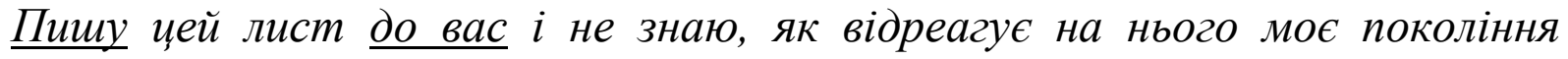
(«Літературна Україна»); Ось полюбуйтеся, щзо вони писали мені за вас! (С. Васильченко).

Шестивалентні дієслова «перенесення» відносять до акціональнолокативних предикатів, які поєднують в собі семантику переміщення i конкретної фізичної дії, а також вказують на передачу об'єкта певному адресату: нести, вносити, виносити, відносити, доносити, заносити, зносити, наносити, надносити, приносити, переносити, підносити, проносити, розносити i под. Поряд 3 адресатною синтаксемою обов'язковими в семантико-синтаксичній структурі речення є компоненти із функціями суб’єкта дії, об’єкта дії, вихідного і кінцевого пункту руху, шляху руху, хоча в системі мовлення багато з них можуть не мати лексичного вираження. Напр.: Ніхто для всіх не принесе і щзро не оддасть, якщо самі ї̈ ми не обстойм (О. Богачук); Ганс сам почав підносити тяжкі иебри до Віри

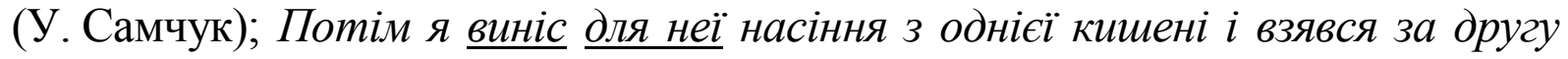
(М. Стельмах); Ти прийдеш $i$ принесеш гроші за баранів матбах-еміні (П. Загребельний); Нащчо їй тепер впізнавати Марію, коли Даруся яйия $\underline{\partial о}$ mama не носить (М. Матіос); Довідавиись, щуо Борис несе до Марусі квіти, вона занервувала («Вісник»); Конюх носив заміс тіткам... (С. Гуцало).

Аналогічно субстанціальної синтаксеми у функції адресата дії вимагають семивалентні дієслова із семантикою «перевезення, доставки об’єкта певному адресату», які також поєднують в собі значення переміщення й конкретної фізичної дії, проте мають здатність валентно сполучатися з усіма іменниковими синтаксемами елементарного простого речення: везти, вивозити, відвозити, завозити, звозити, навозити, надвозити, перевозити, позвозити, привозити, відправляти, відтранспортовувати, доставляти, експортувати, відекспортовувати, доекспортовувати, імпортувати, відімпортовувати, доімпортувати та ін. Напр.: - Пров'янт

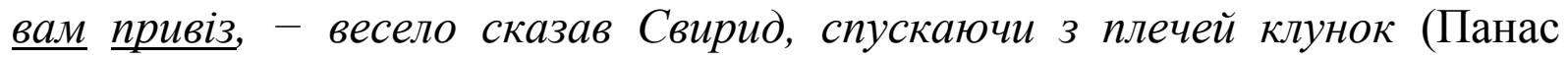
Мирний); Жолкєвський видав наказ, яким забороняв під страхом смерті надвозити або продавати запорозькому війську будь-яку живність чи харч (3. Тулуб); Багато таких суден тепер списують, ріжуть, вантажать на платформи й відправляють на металургійні заводи (О. Гончар).

У позиції предиката можуть виступати не тільки особові дієслівні форми, а й похідні від них дієприкметники, дієприслівники, форми на -но, то, пор.: Нобелівська премія видана для Пабло Неруди 1967 р. («Зарубіжна література»); Всеукраӥнським Центральним Виконавчим комітетом надано право дійсному членові Української Академіӥ наук Михайлові Сергійовичу Грушевському свобідного проживання в межах УРСР («Чорна книга України»); Цей запис було зроблено для студентів і викладачів (В. Сологуб). 
Адресатну синтаксему передбачають також абстрактні іменники, утворені від наведених вище груп дієслів. Це віддієслівні іменники із семантикою «давання»: адресування, вручення, доручення, дарування, видання, видача, надання, передавання, передача, подавання, подання, подача, присвячення, присвята, платіж, позичання, позика, надсилання і под., «писання»: писання, виписування, відписування, вписування, дописування, надписування, переписування, підписування і т. ін.; «перенесення»: несіння, внесення, винесення, віднесення, донесення, занесення, знесення, нанесення, перенесення, піднесення, рознесення та ін.; «перевезення»: вивезення, відвезення, завезення, навезення, надвезення, перевезення, привезення, відправляння, доставка, експортування, імпортування тощо. Вони характерні для субстантивних словосполучень, на основі яких структуруються семантично неелементарні прості речення, що найчастіше вживаються в текстах публіцистичного, ділового та наукового стилів літературної мови. Напр.: Надання кредитів для людей відбувається у всіх відділеннях Приватбанку; Переданням майна вважається вручення його набувачеві або перевізникові, організачуї тощу; Кабінет Міністрів Украӥни дав доручення Державному Комітету телебачення $i$ радіомовлення забезпечити сурдопереклад; Затверджено надіслання та вручення адресатам запитів про надання інформачії; Відбулося вручення премії вітчизняним музикантам; Здійснилось принесення Доброї Новини для жителів Воркути; Для написання листа матері він взявся ввечері (3 газети).

Синтаксема у функції адресата стану валентно сполучається тільки 3 прикметниковими предикатами винници, винуватий (у значенні «який має борг»), що за семантикою наближаються до дієслова «заборгувати» i прогнозують у правобічній валентній позиції ще об'єктного компонента, вираженого іменниками на позначення грошових одиниць (гривня, копійка, карбованець, долар, євро), а також предметів побуту та істот (крім осіб), напр.: Позичальник винний банкові значну суму («Вісник»). Лексичне наповнення адресатної синтаксеми передбачає обов'язкову номінацію людей, рідше тварин. Назви неживих предметів можливі лише за умови метафоризації, персоніфікації понять. Як бачимо, адресатна синтаксема як облігаторний компонент речення виступає при обмеженій групі предикатів дії або стану. Факультативний іï вияв характеризується, хоча й меншим ступенем необхідності, проте набагато ширшими сполучувальними можливостями. Іноді сема адресатності може формуватися залежно від контексту. Білышість дієслів самостійно не виявляють адресатної спрямованості, однак повністю заперечити іiі відсутність не можна, бо «кожну дію чи стан, оскільки вони регулюються свідомістю, можна адресувати комусь» [5, с. 269]. У відповідних контекстах значна кількість дієслів здатна передбачати факультативний адресатний компонент, який легко можна вилучити з речення без істотних змін у його семантиці. Це насамперед дієслівні предикати із значенням: а) мовленнєвої, розумової, 
емоційно-психічної діяльності: говорити, доповідати, доносити, звертатися, казати, наказувати, повідомляти, розповідати, співати, читати, шептати, демонструвати, показувати, доводити, заперечувати, пояснювати, роз'яснювати, розкривати, посміхатися, залицятися тощо, напр.: Критик не говорив тобі нічого більше, не мотивував свойого суду (I. Франко); Дядя Коля оповідав йому багато про війну, про тяжкі бої (В. Гжицький); Кармазин спокійно повідомляв Сагайді, щзо одержав оце трохи поповнення, молодих, необстріляних (О. Гончар); Жартувать добре в родині, а нащзо ж тато проповідує се мужикам (М. Коцюбинський); Кілька свят та неділь викладав він своїм слухачам українську історію (Б. Грінченко); б) фізичної дії: будувати, варити, вибирати, виготовляти, вишивати, готувати, збирати, жати, косити, малювати, набирати, накладати, накидати, наливати, насипати, обробляти, підсипати, підкидати, садити, танцюювати, цити; ламати, палити, руйнувати, розв'язувати та ін., напр.: А в Миргороді мітинг велелюдний Біля підніжжя пам'ятника того, Що спорудив поетові народ (М. Рильський); Княжні своїи маленькій Сорочечки шила [княгиня]. I маленькі рукавчата Шовком вишивала (Т. Шевченко); Цю гру-саморобку виготовляють для дітей дошкільного віку («Експрес»); Хотів би я змалювати тобі краєвид на мечеть - та далебі не маю часу (М. Коцюбинський); Брати! Вина! Вина мені насипте! (М. Бажан). Контекстне розширення кола дієслів «давальної семантики» спричиняє в останніх поступову втрату, «розмивання» семи конкретної безпосередньої дії, що $\epsilon$ необхідною умовою значення адресатності [2, с. 29].

Як видно 3 наведених прикладів, у граматичній системі сучасної української мови основним морфологічним варіантом адресатної синтаксеми і єдиною іï безприйменниковою формою виступає давальний відмінок, що відтворює насамперед функцію адресата дії у семантично елементарних простих реченнях, де навколо дієслівного предиката згруповані суб'єкт, який через об’єкт діє на особу-адресата. Лексичне наповнення такого давального охоплює назви осіб, що дало змогу узагальнити майже всі його семантико-синтаксичні різновиди під назвою «давальний особи» [7, с. 32].

Паралельно з давальним відмінком все активніше в напівпериферійній позиції речення вживаються прийменниково-відмінкові форми для вираження адресатної функції. Цьому сприяють у граматичній системі сучасної української мови ті зміни, які стосуються співвідношення синтетичних і аналітичних форм, а саме тенденції до розвитку аналітизму. Наприклад, родовий з прийменником для, пересуваючись 3 детермінантної (а отже периферійної) в нецентральну-непериферійну позицію речення, нейтралізує своєю цільову семантику і стає функціональним еквівалентом давального відмінка адресата. Крім функції адресата дії, він вносить у конструкцію додатковий значеннєвий відтінок призначення, напр.: Pута дала 
для свого сина чудернацььке ім'я-Овлур (В. Малик); Купелю й одяг передайте для моӥх гостей (П. Загребельний); М.Вінграновський написав низки книжок для дітей (І. Дзюба); Дарунки везу для хана Батия від мого воєводи (П. Загребельний); Спеціально для неї ми підготували святкове меню («Порадниця»). За таким же принципом відбувається переміщення прийменника до з родовим відмінком, але 3 просторової позиції, напр.: Кастильська етикета наказує звертатися до дами: "Дозвольте, пані, стати на коліна» (Леся Українка); Через свого прес-секретаря співачка звернулася до представників ЗМI («Експрес»); Переказує піп через людей до Івана, щзоби йшов дожинати (Л. Мартович); Видно, люблять сю дівчину усі - так ласкаво до неї усміхаються (Г. Хоткевич); - Ще наче вчора був молодим, до дівчат личявся... (О. Гончар). Прийменник перед з орудним відмінком може пересуватися із детермінантної позиції речення в напівпериферійну, перетворюючись на функціональний еквівалент давального у функції адресата, пор.: Невимовної краси картини розкриваються перед льотчиками (О. Довженко) і Невимовної краси картини розкриваються льотчикам.

Отже, адресат дії $\epsilon$ основним семантичним варіантом адресатної синтаксеми. Лише при тривалентних предикативних прикметниках винний, винуватий із значенням «який має борг» вживається облігаторна субстанціальна синтаксема у функції адресата стану. Ступінь обов'язковості адресата дії при різних дієсловах неоднакова. Якщо відсутність адресатної синтаксеми призводить до змістової або граматичної недостатності речення, то вона є обов'язковим компонентом речення, і навпаки, коли усунення адресата не впливає на інформаційну навантаженість речення, то він $є$ факультативним компонентом речення.

У пропонованій статті зосереджено увагу лише на одному з аспектів вивчення категорії адресатності, а саме іiі семантичній диференціації та морфологічному варіюванні. Подальші наукові розвідки в цьому плані передбачають грунтовний опис формально-синтаксичних і комунікативних варіантів адресатної мінімальної семантико-синтаксичної одиниці, що дасть змогу здійснити іï системний функціональний аналіз.

\section{Література}

1. Андерш Й. Ф. Типологія простих дієслівних речень у чеській мові в зіставленні з українською / Й. Ф. Андерш. - К. : Наук. думка, 1987. -191с.

2. Безпояско О. К. Граматика української мови. Морфологія / О. К. Безпояско, К. Г Городенська, В. М. Русанівський. - К. : Либідь, 1993. - 336 с.

3. Вихованець І. Р. Нариси з функціонального синтаксису української мови/ І. Р.Вихованець. - К. : Наук. думка, 1992. -222 с.

4. Вихованець І. Р. Теоретична морфологія української мови : Академ. граматика укр. мови / І. Р Вихованець, К. Г. Городенська; За ред. І. Вихованця. - К. : Унів. вид-во «Пульсари», 2004. - 400 с.

5. Пешковский А. М. Русский синтаксис в научном освещении / А. М. Пешковский. - 7-е изд. - М. : Учпедгиз, 1956. - $511 \mathrm{c.}$

6. Плющ М. Я. Категорії суб’єкта і об’єкта в структурі простого речення / М. Я. Плющ. - К.: Вища шк., $1986 .-175 \mathrm{c}$.

7. Тимченко Є. К. Номінатив і датив в українській мові / Є. К. Тимченко. - К. : Вид-во ВУАН, 1926. - 118 с. 